Email: jkesislam@unisma.ac.id

Home Page : http://riset.unisma.ac.id/index.php/jki

\title{
PERBEDAAN TINGKAT PENGETAHUAN DAN POLA PERILAKU PENCEGAHAN HIPERKOLESTEROLEMIA SETELAH PENYULUHAN POLA MAKAN PADA PENDIDIK DAN TENAGA KEPENDIDIKAN PERGURUAN TINGGI DI MALANG
}

Risna Bekty Karyani, Rizki Anisa, Erna Sulistyowati*

Fakultas Kedokteran Universitas Islam Malang (UNISMA)

\begin{abstract}
ABSTRAK
Pendahuluan: Penyakit jantung koroner menjadi 1/3 penyebab kematian di dunia pada 2001 dan diperkirakan akan terus meningkat. Penyakit jantung koroner disebabkan aterosklerosis, aterosklerosis dapat dipicu oleh hiperkolesterolemia. Salah satu faktor yang menyebabkan hiperkolesterolemia adalah pola makan yang buruk. Pola makan yang buruk muncul karena pegetahuan yang kurang tentang pola makan seimbang untuk menjaga kesehatan. Penelitian ini bertujuan meningkatkan pengetahuan tentang hiperkolesterolemia dan penceghannya dengan mengatur pola makan.

Metode: Penelitian ini adalah penelitian eksperimental one group pre test post test. Responden adalah laki-laki dan perempuan berusia $\geq 40$ tahun yang berkerja sebagai pendidik dan tenaga kependidikan perguruan tinggi di Malang. Data didapatkan dari menjawab soal pre test dan kuesioner diawal peneltian. Peneliti memberikan penyuluhan kesehatan, lalu responden menjawab soal post test dan kuesioner akhir. Analisa data dilakukan dengan uji Wilcoxon, hasil signifikan apabila $p<0,05$.

Hasil: Hasil analisa statistik terhadap nilai pre test dan post test menunjukkan adanya perbedaan bermakna dengan nilai $p<0,05$. Uji analisis statistik kuesioner diawal-akhir menunjukkan adanya perubahan pola perilaku makan diet tinggi lemak menjadi pola perilaku makan seimbang yang signifikan dari keseluruhan responden dengan nilai $p<0,05$.
\end{abstract}

Kesimpulan: Penyuluhan kesehatan meningkatkan mengetahuan tentang hiperkolesterol dan pola perilaku makan diet tinggi lemak dan merubah pola perilaku makan.

Kata Kunci : Penyuluhan kesehatan, hiperkolesterolemia, pola makan

*Korespondensi :

Erna Sulistyowati, dr. M.Kes,. P.hD.

Jl. MT. Haryono. 193 Kota Malang, Jawa Timur, Indonesia, 65144

e-mail: ernafkunisma@gmail.com phone: 0341578920

\section{DIFFERENCES OF KNOWLEDGE LEVELS AND BEHAVIOR PATTERNS OF HYPERCHOLESTEROLEMIA PREVENTION AFTER DIETARY COUNSELING FOR EDUCATORS AND EDUCATIONAL PERSONNEL IN MALANG}

Risna Bekty Karyani, Rizki Anisa, Erna Sulistyowati*

Faculty of Medicine, University of Islam Malang (UNISMA)

\begin{abstract}
Background: Coronary heart disease became one third of the causes of death in the world in 2001 and is expected to continue to increase. Coronary heart disease is caused by atherosclerosis, atherosclerosis can be triggered by hypercholesterolemia. One of the factors that cause hypercholesterolemia is a poor diet. Poor diet arises because of inadequate knowledge of a balanced diet to maintain health. This study aims to increase knowledge about hypercholesterolemia and how to prevent it by adjusting diet.

Method: This research is an experimental research one group pretest posttest. Respondents were males and females aged $\geq 40$ years who worked as educators and higher education personnel in Malang. The data collection method used was to answer pre-test questions and questionnaires at the beginning of the study. Then, given health education and the respondents answered questions on the post test and the final questionnaire. Data analysis was performed using the Wilcoxon test with a significance level of $p<0,05$.

Result: The results of statistical analysis on the pre-test and post-test values of respondents showed a significant difference with $p<0.05$. The statistical analysis test of the questionnaire at the beginning and end showed a significant change in the eating behavior pattern of a high-fat diet into a balanced eating behavior pattern for all respondents with $p<0.05$.
\end{abstract}

Conclusion: Health education increases knowledge about hypercholesterolemia and eating behavior patterns on a high-fat diet and changes eating behavior patterns.

Keyword : Health education, hypercholesterolemia, diet 


\section{PENDAHULUAN}

Penyakit jantung koroner menjadi penyebab utama kematian di dunia. Sekitar 1/3 kematian disebabkan oleh penyakit kardiovaskuler pada tahun 2001 dan diperkirakan akan terus mengalami peningkatan pada tahun 2020 melebihi tingkat kematian karena kecelakaan. ${ }^{5}$ Penyakit kardiovaskuler bisa disebabkan karena terjadinya aterosklerosis. Aterosklerosis salah satunya disebabkan oleh hiperkoleserolemia. ${ }^{4}$ Hiperkolesterolemia adalah keadaan ketika kadar kolesterol dalam darah lebih dari $200 \mathrm{mg} / \mathrm{dl}$, salah satu faktor penyebab hiperkolesterolemia adalah pola makan yang buruk. ${ }^{2}$

Perkembangan kehidupan yang terjadi telah mempengaruhi kebiasaan hidup masyarakat, termasuk kebiasaan makan. Berdasarkan data Survei Konsumsi Makanan Individu (SKMI) oleh Badan Litbangkes 2014. Didapatkan hasil konsumsi gula lebih dari 50 gram, natrium $(\mathrm{Na})$ lebih dari 2000 milligram (mg), yang setara dengan 5 gram $\mathrm{NaCl}$, dan lemak total lebih dari 67 gram/orang per hari konsumsi tersebut melebihi kebutuhan harian yang sudah ditetapkan oleh WHO. ${ }^{1}$ Buku Biokimia Harper (2014) dijelaskan bahwa asam lemak jenuh dan asam lemak trans memiliki efek sama dalam menimbulkan adanya hiperkolesterolemia dan aterosklerosis Hasil Riskesdes tahun 2013 proporsi penduduk Indonesia usia >30 tahun dengan kolesterol diatas normal lebih tinggi pada perempuan yakni $39.9 \%$ dibandingkan laki-laki $30 \% .^{2}$

Pekerjaan menjadi salah satu faktor yang mempengaruhi pola makan seseorang. Pekerjaan membuat seseorang memiliki waktu singkat dalam memenuhi kebutuhan makan, sehingga memilih makanan yang cepat dalam proses penyajian. Salah satu contohnya adalah Pegawai Negeri Sipil (PNS) yang merupakan pegawai kantoran. Dalam penelitian yang dilakukan oleh Damanik (2013) dari data yang diperoleh terbukti bahwa PNS di Kanwil Direktorat Jendral Perbendaharaan Kota Medan sering mengkonsumsi makanan daging, telur, ampela/ati, dan gorengan, pengukuran ratarata kadar kolesterol mereka $210,8 \mathrm{mg} / \mathrm{dl}^{3}{ }^{3}$

Salah satu penyebab hiperkolesterolemia adalah rendahnya pengetahuan sehingga mempengaruhi pola perilaku masyarakat. Dalam penelitian yang dilakukan Muhasidah et al (2017) didapatkan kesimpulan bahwa tingkat pengetahuan memiliki hubungan bermakna dengan kadar glukosa darah pasien diabetes melitus tipe 2.5 Berdasarkan penelitian tersebut, pengetahuan mempengaruhi pola perilaku masyarakat. Tingkat pengetahuan tentang pola makan mempengaruhi kebiasaan makan. Oleh karena itu, dengan diadakannya penyuluhan ini dapat menambah pengetahuan dan mampu memperbaiki kebiasaan makan. ${ }^{6}$

\section{Desain, Waktu dan Tempat Penelitian}

Penelitian ini adalah penelitian eksperimen one group pre test post test, dan diberikan penyuluhan kesehatan. Peneltitian dilaksanakan di lingkungan perguruan tinggi Malang. Penelitian dilakukan dalam kurun waktu Bulan Juli-Agustus 2020. Penelitian ini telah mendapatkan persetujuan dari Komisi Etik Penelitian Kesehatan Rumah Sakit Islam Malang

\section{No.31/VII/2020/KEPK.RSIUNISMA}

\section{Instrumen Penelitian}

Pada penelitian ini menggunakan soal pretest dan posttest 10 pertanyaan yang berisi tentang penyakit hiperkolesterolemia dan cara pencegahannya. Hasil dikatakan kurang ketika responden hanya mampu menjawab 1-5 soal, cukup ketika responden mampu menjawab 6-7 soal, dan baik ketika mampu menjawab $8-10$ soal. $^{16}$

Kuesioner AFHC (Adolescent Food Habits Checklist) yang berisi 23 pertanyaakan yang menanyakan seputar kebiasaan makan responden. Hasil buruk ketika jumlah nilai nya dibawah ratarata seluruh responden, dan baik ketika jumlah nilai nya diatas rata-rata seluruh responden.

\section{Sarana Prasarana Penelitian}

Pada penelitian ini dilakukan penyuluhan kesehatan dengan media infografis dan video edukasi yang dibagikan di grup WhatsApp. Infografis berisi tentang insiden dan prevalensi, faktor resiko, dan pola makan untuk mencegah penyakit hiperkolesterolemia. Video edukasi membahas tentang penyakit hiperkolesterolemia dan pola makan untuk mencegahnya.

Google form digunakan untuk mengisi skrining kesehatan calon responden, mengisi kuesioner awal-akhir, dan menjawab soal pre test dan post test.

\section{Uji Kuesioner}

Pada penelitian ini menggunakan kuesioner AFHC (Adolescent Food Habits Checklist) berbahasa Inggris yang diterjemahkan ke dalam bahasa Indonesia, lalu diadaptasikan sesuai tempat penelitian. Peneliti melakukan uji keterbacaan, validitas, dan reliabilitas terhadap 30 orang diluar responden penelitian.

\section{METODOLOGI}




\section{Penentuan Responden Penelitian}

Perjalanan alur penelitian penentuan responden

Gambar 1 di bawah ini :

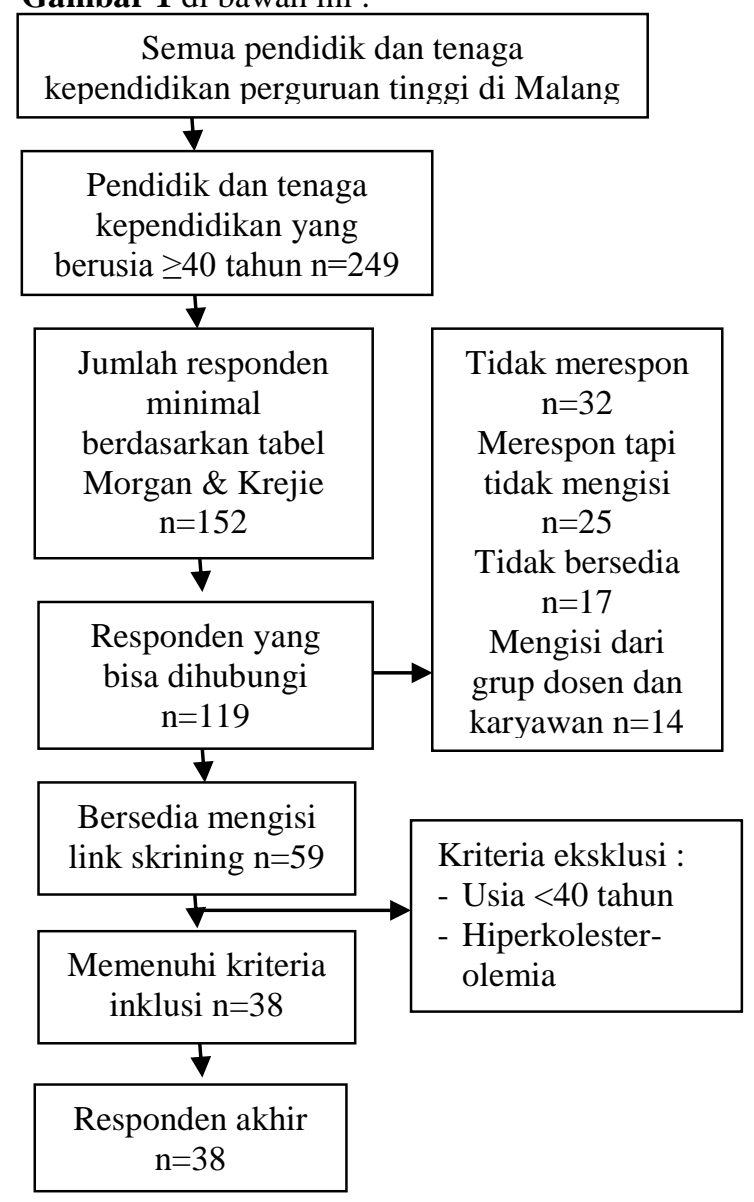

Gambar 1 Diagram Alur Penentuan Responden

Keterangan: Gambar 1 menjelaskan alur penentuan responden penelitian.

\section{Mengisi Pre test dan Post test}

Responden mengisi pre test sebelum penyuluhan kesehatan dan post test 2 minggu setelah penyuluhan kesehatan melalui tautan google form.

\section{Penyuluhan Kesehatan}

Penyuluhan kesehatan menggunakan media grup whatsapp dengan membagikan infografis dan video edukasi. Penyuluhan dilakukan selama 3 hari. Peneliti membagikan infografis tentang penyakit hiperkolesterolemia di hari pertama penyuluhan. Peneliti membagikan infogrfis tentang pola makan pencegahan hiperkolesterolemia di hari kedua. Peneliti membagikan video edukasi tentang penyakit dan pola makan pencegahan hiperkolesterolemia

Peneliti melakukan follow up pada responden dengan WhatsApp pribadi menanyakan tentang makanan yang dikonsumsi.

\section{Analisis Data}

Pada penelitian ini menggunakan analisis statistik uji Chi square uji Wilcoxon. Hasil dikatakan bermakna bila $p<0,05$.

\section{HASIL PENELITIAN}

\section{Karakteristik Responden Penelitian}

Pada penelitian ini didapatkan 38 responden yang memenuhi kriteria inklusi. Karakteristik responden yang diamati antara lain jenis kelamin, pekerjaan, dan usia.

\section{Karakteristik Responden Berdasarkan Tingkat Pengetahauan}

Hasil dan analisa dan tentang karakteristik responden terhadap tingkat pengetahuan sebelum penyuluhan pada Tabel 1 dan setelah penyuluhan pada Tabel 2

Tabel 1 Karakteristik Responden Berdasarkan Tingkat Pengetahuan Sebelum Diberikan Penyuluhan

\begin{tabular}{|c|c|c|c|c|c|c|c|}
\hline \multirow{2}{*}{ No. } & \multirow{2}{*}{\multicolumn{2}{|c|}{ Karakteristik }} & \multirow{2}{*}{ Jumlah } & \multicolumn{3}{|c|}{ Tingkat Pengetahuan } & \multirow{2}{*}{$p$} \\
\hline & & & & Buruk & Cukup & Baik & \\
\hline \multirow[t]{2}{*}{1.} & Jenis kelamin & Laki-laki & $19(50 \%)$ & 1 & 10 & 8 & \multirow{2}{*}{0,736} \\
\hline & & Perempuan & $19(50 \%)$ & 2 & 8 & 9 & \\
\hline \multirow[t]{2}{*}{2.} & Pekerjaan & Pendidik & $\begin{array}{c}25 \\
(65,8 \%)\end{array}$ & 1 & 10 & 14 & \multirow[b]{2}{*}{0,116} \\
\hline & & $\begin{array}{l}\text { Tenaga } \\
\text { Kependidikan }\end{array}$ & $\begin{array}{c}13 \\
(34,2 \%)\end{array}$ & 2 & 8 & 3 & \\
\hline \multirow[t]{3}{*}{3.} & Usia & 40-49 tahun & $\begin{array}{c}10 \\
(26,3 \%)\end{array}$ & 2 & 4 & 4 & \multirow{3}{*}{0,237} \\
\hline & & 50-59 tahun & $\begin{array}{c}23 \\
(60,5 \%)\end{array}$ & 1 & 13 & 9 & \\
\hline & & $\geq 60$ tahun & $5(13,2 \%)$ & 0 & 1 & 4 & \\
\hline
\end{tabular}

Keterangan:

Tabel 1 merupakan karakteristik responden penelitian dalam presentase berdasarkan jenis kelamin, pekerjaan, dan rentang usia terhadap tingkat pengetahuan sebelum diberikan penyuluhan. Hasil tidak bermakna dengan nilai $p>0,05$. 
Tabel 2 Karakteristik Responden Berdasarkan Tingkat Pengetahuan Setelah Diberikan Penyuluhan

\begin{tabular}{|c|c|c|c|c|c|c|c|}
\hline \multirow{2}{*}{ No. } & \multirow{2}{*}{\multicolumn{2}{|c|}{ Karakteristik }} & \multirow{2}{*}{ Jumlah } & \multicolumn{3}{|c|}{ Tingkat Pengetahuan } & \multirow[b]{2}{*}{$p$} \\
\hline & & & & Buruk & Cukup & Baik & \\
\hline \multirow[t]{2}{*}{1.} & Jenis kelamin & Laki-laki & $19(50 \%)$ & 0 & 2 & 17 & \multirow{2}{*}{0,547} \\
\hline & & Perempuan & $19(50 \%)$ & 0 & 1 & 18 & \\
\hline \multirow[t]{2}{*}{2.} & Pekerjaan & Pendidik & $\begin{array}{c}25 \\
(65,8 \%)\end{array}$ & 0 & 1 & 24 & \multirow{2}{*}{0,217} \\
\hline & & $\begin{array}{l}\text { Tenaga } \\
\text { Kependidikan }\end{array}$ & $\begin{array}{c}13 \\
(34,2 \%)\end{array}$ & 0 & 2 & 11 & \\
\hline \multirow[t]{3}{*}{3.} & Usia & 40-49 tahun & $\begin{array}{c}10 \\
(26,3 \%)\end{array}$ & 0 & 1 & 9 & \multirow{3}{*}{0,775} \\
\hline & & 50-59 tahun & $\begin{array}{c}23 \\
(60,5 \%)\end{array}$ & 0 & 2 & 21 & \\
\hline & & $\geq 60$ tahun & $5(13,2 \%)$ & 0 & 0 & 5 & \\
\hline
\end{tabular}

Keterangan:

Tabel 2 merupakan karakteristik responden penelitian dalam presentase berdasarkan jenis kelamin, pekerjaan, dan rentang usia terhadap tingkat pengetahuan setelah diberikan penyuluhan. Hasil tidak bermakna dengan nilai $p>0,05$.

\section{Karakteristik Responden Berdasarkan Pola Perilaku Makan}

Hasil dan analisa data tentang karakteristik responden berdasarkan pola perilaku makan sebelum dilakukan penyuluhan kesehatan. Pada Tabel 3 menyajikan tentang hasil analisa data jenis kelamin responden berdasarkan pola perilaku makan sebelum dan setelah penyuluhan kesehatan, hasil analisa data pekerjaan berdasarkan pola perilaku makan sebelum dan setelah penyuluhan kesehatan, dan hasil analisa data usia berdasarkan pola perilaku makan sebelum dan setelah penyuluhan kesehatan.

Pada Tabel 3 didapatkan hasil semua nilai p>0,05 yang berarti jens kelamin, pekerjaan, dan usia tidak berpengaruh terhadap pola perilaku makan responden sebelum penyuluhan dan sesudah penyuluhan.

Tabel 3 Karakteristik Responden Berdasarkan Pola Perilaku Makan Sebelum Dan Setelah Diberikan Penyuluhan

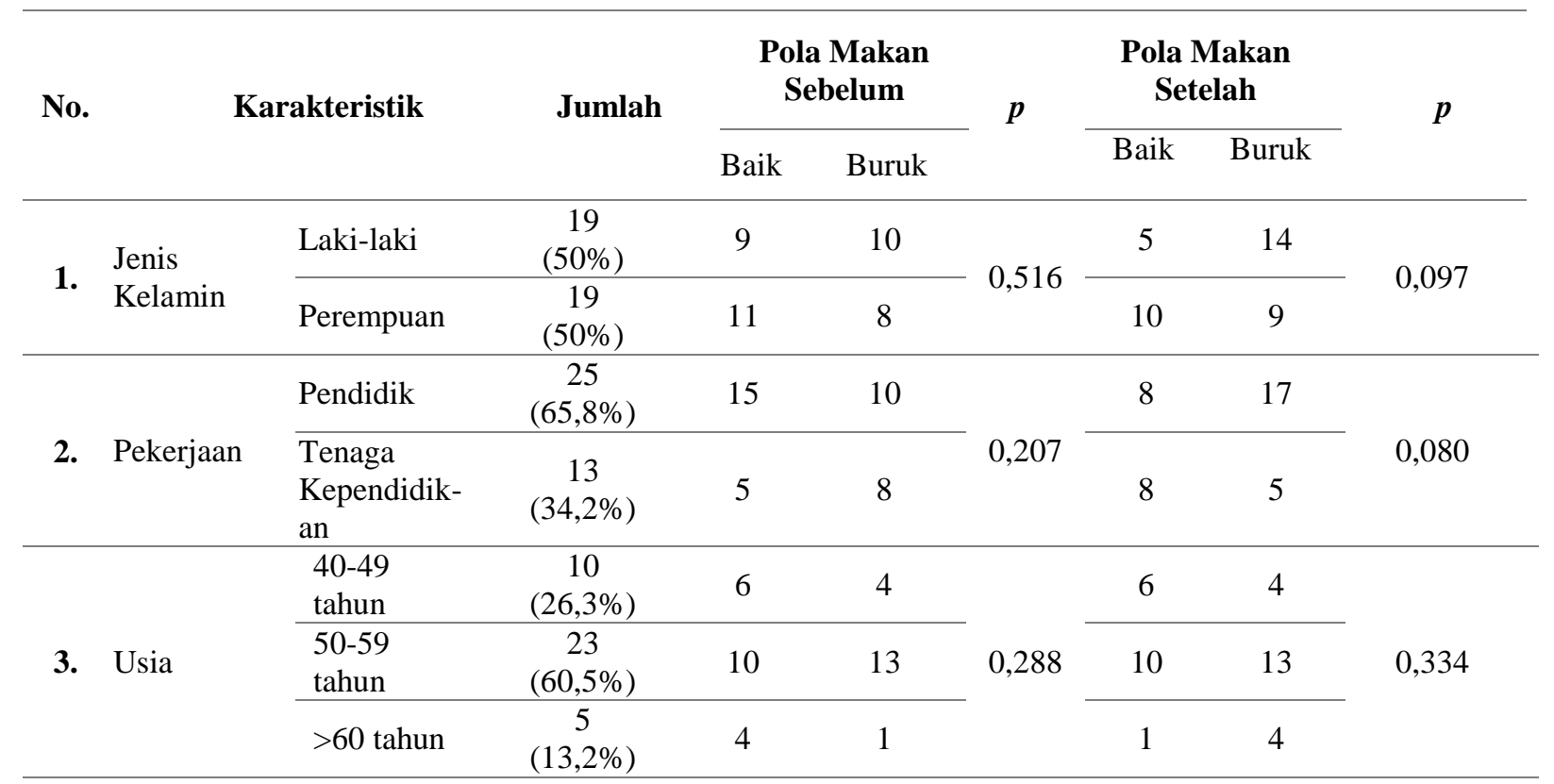

Keterangan:

Tabel 3 merupakan karakteristik responden penelitian dalam presentase berdasarkan jenis kelamin, pekerjaan, pekerjaan, dan rentang usia terhadap pola perilaku makan sebelum diberikan penyuluhan. Hasil tidak bermakna dengan nilai $p>0,05$. 
Hasil Dan Analisa Data Penyuluhan Terhadap Tingkat Pengetahuan

\begin{tabular}{|c|c|c|c|}
\hline $\begin{array}{l}\text { Variabel } \\
\text { Penelitian }\end{array}$ & Pre test & $\begin{array}{c}\text { Post } \\
\text { test }\end{array}$ & $p$ \\
\hline $\begin{array}{l}\text { Tingkat } \\
\text { Pengetahuan }\end{array}$ & $\begin{array}{l}71,05 \pm \\
10,34\end{array}$ & $\begin{array}{c}83,95 \pm \\
7,55\end{array}$ & 0.000 \\
\hline
\end{tabular}

Keterangan:

Tabel 4 merupakan rata-rata nilai pre test dan post test dan \pm Standar Deviasi (SD). Uji statistik didapatkan perbedaan yang signifikan menggunakan uji Wilcoxon dengan $p<0,05$.

Tabel 5 Hasil Uji Wilcoxon Nilai Pretest dan Posttest

\begin{tabular}{lccc}
\hline \multirow{2}{*}{ Tingkat } & \multicolumn{2}{c}{ Nilai } & $\boldsymbol{p}$ \\
\cline { 2 - 3 } Pengetahuan & Pre test & Post tes & \\
\hline Hiperkolesterol & $84,21 \pm$ & $92,12 \pm$ & 0.008 \\
& 20,11 & 14,36 & \\
\hline Pola Perilaku & $64,68 \pm$ & $79,70 \pm$ & 0.000 \\
Makan & 14,68 & 10,31 & \\
\hline
\end{tabular}

Keterangan :

Tabel 5 merupakan rata-rata nilai pre test dan post test dan \pm Standar Deviasi (SD) tentang hiperkolesterol dan pola perilaku makan. Uji statistik didapatkan perbedaan yang signifikan menggunakan uji Wilcoxon dengan $p<0,05$.

\section{Hasil Dan Analisa Data Penyuluhan Terhadap Pola Perilaku Makan}

\section{Tabel 6 Hasil Uji Wilcoxon Pola Perilaku Makan}

\begin{tabular}{lccc}
\hline $\begin{array}{l}\text { Variabel } \\
\text { Penelitian }\end{array}$ & Pre & Post & $\boldsymbol{p}$ \\
\hline $\begin{array}{l}\text { Pola } \\
\text { Perilaku }\end{array}$ & $33,42 \pm 5,11$ & $36,16 \pm 4,15$ & 0.000 \\
Makan & & & \\
\hline
\end{tabular}

Keterangan:

Tabel 6 merupakan skor kuesioner awal-akhir dan \pm Standar Deviasi (SD). Uji statistik didapatkan perbedaan yang signifikan menggunakan uji Wilcoxon dengan $p<0,05$.

\section{PEMBAHASAN}

Peran Karateristik Responden Berdasarkan Tingkat pengetahuan Dan Pola Perilaku Makan

Pendidik dan Tenaga Kependidikan Di UNISMA yang berusia $\geq 40$ tahun sebanyak 249 yang dibulatkan menjadi 250, sehingga berdasarkan Morgan n' Krejie Table jumlah responden minimal sebanyak 152. Ada 119 orang yang bisa dihubungi. Setelah dilakukan pembagian formulir skrining selama 3 hari, ada yang tidak merespon sebanyak 32 orang, merespon tapi tidak mengisi 25 orang, tidak merespon 17 orang, dan mengisi dari grup dosen dan karyawan sebanyak 14 orang. Total responden yang mengisi fromulir skrining sebanyak 59 orang dan yang memenuhi kriteria inklusi sebanyak 38 responden.

\section{Karakteristk Responden Berdasarkan Tingkat}

\section{Pengetahuan}

Pada penelitian ini terdapat 38 responden dalam satu group pre test post test berjenis kelamin laki-laki dan perempuan. Responden bekerja sebagai pendidik dan tenaga kependidikan perguruan tinggi di Malang yang terbagi dalam 3 rentang usia, yaitu : usia 40-49 tahun, usia 50-59 tahun, dan usia $\geq 60$ tahun. Berdasarkan analisis statistik menggunaka chi square, didapatkan hasil yang tidak signifikan antara jenis kelamin dengan tingkat pengetahuan sebelum diberikan penyuluhan dan setelah diberikan penyuluhan. Hal ini sejalan dengan penelitian yang dilakukan oleh Ifada (2010), dalam peneitian tersebut didapatkan hasil tidak bermakna antara jenis kelamin dengan pengetahuan masyarakat. ${ }^{18}$ Faktor-faktor yang mempengaruhi pengetahuan adalah usia, tingkat pendidikan, pekerjaan, dan lingkungan social tidak dipengaruhi oleh jenis kelamin. ${ }^{7}$

Sebagian besar responden bekerja sebagai pendidik perguruan tinggi di Malang sebanyak 25 orang. Hasil analisis statistik pada karakteristik ini menunjukkan bahwa jenis pekerjaan tidak berpengaruh signifikan terhadap tingkat pengetahuan baik sebelum diberikan penyuluhan dan setelah diberikan penyuluhan. Hasil tersebut tidak sejalan dengan penelitian yang dilakukan oleh Hardjojo (2012) yang membahas tentang resiko terjadinya penyakit jantung koroner. Dalam penelitian tersebut, didapatkan hasil bahwa status pekerjaan dosen memiliki tingkat penyerapan materi yang lebih tinggi dari pada pegawai administrasi, sehingga rata-rata nilai dosen lebih tinggi. ${ }^{7}$ Tapi pada penelitian ini didapatkan hasil tidak signifikan antara pekerjaan terhadap tingkat pengetahuan. Hal ini dikarenakan pekerjaan responden sebagai pendidik dan tenaga kependidikan yang memiliki jenjang pendidikan tinggi dan bekerja di lingkungan yang sama saling berinteraksi, sehingga tingkatan pengetahuannya tidak terlalu berbeda jauh. ${ }^{12}$

Pada penelitian ini, didapatkan karakteristik usia menunjukkan hasil tidak signifikan yang berarti usia tidak berpengaruh terhadap tingkat pengetahuan responden sebelum dan setelah diberikan penyuluhan, dengan responden paling banyak pada kelompok usia 50-59 tahun. Hasil dalam penelitian ini sejalan dengan penelitian yang dilakukan oleh Ifada (2010) bahwa tidak terdapat hubungan yang bermakna antara usia dengan pengetahuan masyarakat. ${ }^{18}$ Hal ini bisa dikarenakan rentang usia responden yang tidak jauh, usia produktif sehingga kemampuan memahami informasinya setara. ${ }^{7}$

Penyuluhan kesehatan mengunakan media infografis dan video edukasi yang kemudian dilaukan diskusi dalam grup WhatsApp.. Infografis dan video edukasi mampu memberikan pemahaman sebanyak 
$50 \%$ pada responden dan apabila ditambah dengan melakukan diskusi akan memberikan pemahaman hingga $70 \% .{ }^{17}$

\section{Karakteristik Responden Berdasarkan} Pola Perilaku Makan

Pada penelitian ini, hasil uji statistik chi square tidak terdapat hubungan yang bermakna antara jenis kelamin dan pola perilaku makan seseorang. Hal ini sejalan dengan penelitian yang dilakukan Puspitawati (2008) yang didapatkan hasil bahwa kebiasaan makan, frekuensi makan, dan jenis makanan yang dipilih antara laki-laki dan perempuan tidak terdapat perbedaa yang bermakna. ${ }^{19}$ Kebiasaan makan tergantung pada masing-masing orang, sesuai selera jenis makanan yang dipilih dan tidak dipengaruhi jenis kelamin, tapi lebih sering dipengaruhi oleh penghasilan, lingkungan sosial, dan pengetahuan. ${ }^{8}$

Hasil penelitian ini menunjukkan tidak ada hubungan yang bermakna antara jenis pekerjaan dengan pola perilaku makan responden. Hasil tersebut tidak sesuai dengan penelitian sebelumnya yang dilakukan Hardjojo (2012) yang membahas tentang resiko terjadinya penyakit jantung koroner. Dalam penelitian tersebut, didapatkan hasil bahwa status pekerjaan dosen memiliki perubahan sikap yang relative lebih baik dari pada pegawai administrasi. Karena Pekerjaan dosen yang mengejar sehingga lebih cepat menerima dan memahami. ${ }^{7}$ Pada penelitian ini, hasil yang tidak signifikan dikarenakan beberapa responden yang sudah mengatur pola makannya sejak sebelum penelitian ini dilaksanakan karena keyakinan pentingnya menjaga pola hidup sehat sesuai dengan Health Belief Model (HBM) tentang perceived benefit yakni muncul kepercayaan seseorang tentang manfaat yang didapatkan dari perilaku sehat. $^{14}$

Pada penelitian ini juga diperoleh analisis statistik yang menunjukkan tidak ada hubungan signifikan antara usia dengan pola perilaku makan seseorang. Hasil tersebut sejalan dengan penelitian yang dilakukan oleh Ujiani (2015) bahwa usia tidak mempengaruh pola makan dan kadar kolesterol, sehingga usia berapapun apabila memiliki kebiasaan makan yang buruk akan meningkatkan kadar kolesterolnya. ${ }^{20}$ Kebiasaan makan seseorang sering dipengaruhi oleh penghasilan, lingkungan sosial, dan pengetahuan. ${ }^{8}$ Pada penelitian ini beberapa responden sudah mengatur pola makan sejak sebelum penelitian dimulai dengan menghindari beberapa jenis makanan tertentu dan menjaga asupannya karena kesadaran tentang manfaat perilaku sehat. ${ }^{14}$

Perbedaan Tingkat Pengetahuan Makan Sebelum Dan Setelah Penyuluhan
Pada penelitian ini, hasil analisa statistik terhadap nilai pre test dan post test responden menunjukkan adanya perbedaan yang signifikan, dimana nilai post test menjadi lebih tinggi dari nilai pre test. Hal ini berarti penyuluhan kesehatan terbukti memberikan pengaruh terhadap tingkat pengetahuan responden. Hasil ini sejalan dengan penelitian yang dilakukan oleh Hardjojo (2012) yang menunjukkan bahwa penyuluhan kesehatan memberi dampak yang signifikan terhadap peningkatan pengetahuan seseorang terkait resiko terjadinya penykit jantung koroner. ${ }^{6}$

Pada penelitian sebelumnya yang dilakukan oleh Renityas (2020), didapatkan hasil bahwa pemberian pendidikan kesehatan tentang kolesterol memberikan efek dalam peingkatan pengetahuan lansia untuk pencegahan hiperkolesterol. ${ }^{10}$ Naziyah at el (2018) dalam penelitiannya menyebutkan bahwa pendidikan kesehatan berpengaruh terhadap tingkat pengetahuan seseorang, dimana tingkat pengetahuan seseorang akan meningkat setelah diberikan pendidikan kesehatan. ${ }^{11}$

Menurut Sukanto dalam Febriyanto (2016) menjelaskan bahwa tingkat pengetahuan dipengaruhi oleh banyak faktor, salah satunya adalah informasi. Semakin banyak informasi yang didapatkan akan menambah pengetahuannya. ${ }^{12}$ Dalam penelitian ini, penambahan informasi diperoleh dari penyuluhan kesehatan yang diberikan dengan selama 3 hari yang menggunakan media infografis dan video edukasi serta diskusi yang mampu meningatkan pemahaman hingga 70\%. ${ }^{17}$

Pada analisis data nilai pre test post test pengetahuan tentang hiperkolesterol dan pola perilaku makan, terdapat perbedaan yang signifikan. Hal ini menunjukkan adanya peningkatan pengetahuan setelah diberikan penyuluhan kesehatan. Penambahan pengetahuan ini bisa mempengaruhi perubahan perilaku pada sseorang yang sesuai dengan Theory Planned Behavior (TPB) yag menyebutkan bahwa salah satu faktor yang mempengaruhi perilaku adalah attitude, dimana attitude/sikap ini merupakan keyakinan seseorang yang akan mempengaruhi sikap. Keyakinan ini bisa diperoleh dari pengetahuan melalui penyuluhan kesehatan. ${ }^{15}$

\section{Perbedaan Pola Perilaku Makan Sebelum Dan Setelah Penyuluhan}

Pada penelitian ini, didapatkan hasil analisis statistik kuesioner diawal dan akhir menunjukkan adanya perubahan pola perilaku makan yang signifikan dari keseluruhan responden. Hal ini membuktikan bahwa penyuluhan kesehatan yang diberikan dapat mempengaruhi pola perilaku makan responden. Rahman (2016) menyebutkan bahwa pengetahuan yang tepat mengenai pola makan akan diterapkan dalam kehidupan sehari-hari untuk menjaga kesehatan. ${ }^{13}$

Hasil penelitian ini sesuai dengan teori Health Behavior Model (HBM) yang menjelaskan tentang komponen yang mempegaruhi perilaku sehat seseorang. Komponen tersebut adalah perceived 
suscepbility yang membahas tentang kekhawatiran seseorang tentang suatu penyakit sehingga akan melakukan pencegahan, perceived severity tentang kekhawatiran keparahan suatu penyakit sehingga mendorong untuk menghindarinya, dan perceived benefit yang membahas keyakinan tentang manfaat yang diperoleh dari perilaku hidup sehat yang dapat mencegah timbulnya suatu penyakit. ${ }^{14}$

Berdasarkan dari pembahasan pada penelitian ini terdapat kekurangan. Kekurangan tersebut meliputi : jumlah responden jauh dari batas minimalnya yang mempengaruhi hasil dan analisa data, dan penelitian yang dilakukan secara online sehingga peneliti tidak bisa mengobservasi saat responden mengisi kuesioner dan menjawab soal.

\section{KESIMPULAN}

Berdasarkan analisa data dan pembahasan dapat disimpulkan bahwa :

1. Penyuluhan kesehatan meningkatkan pengetahuan tentang hiperkolesterolemia dan pentingnya menjaga pola makan seimbang untuk pencegahan hiperkolesterolemia.

2. Penyuluhan kesehatan mampu mengubah pola perilaku makan diet tinggi lemak menjadi pola perilaku makan seimbang pencegahan hiperkolesterolemia.

\section{SARAN}

Pada penelitian ini, peneliti menyarankan agar :

1. Melakukan penelitian secara offline atau tatap muka, sehingga dapat dilakukan observasi pada responden secara menyeluruh.

2. Melakukan penelitian dalam jangka waktu yang lebih lama untuk memberikan kesempatan responden melakukan perubahan pola perilaku makan responden.

3. Melakukan pemeriksaan kadar kolesterol untuk memastikan hasil skrining.

4. Peneliti menyarankan hasil penelitian ini dapat dijadikan landasan untuk mengembangkan penelitian tentang seberapa besar tingkat pengetahuan dapat mempengaruhi pola perilaku.

\section{UCAPAN TERIMA-KASIH}

Terimakasih disampaikan kepada IOM (Ikatan Orangtua Mahasiswa) dan Fakultas Kedokteran Universitas Islam Malang yang telah mendanai penelitian ini.

\section{DAFTAR-PUSTAKA}

[1] Atmarita, Abas B. Jahari, Sudikno, dan Moesijanti Soekarti. 2015. Asupan Gula, Garam, dan Lemak di Indonesia : Analisis Survei Konsumsi Makanan Individu (SKMI) 2014. Journal of The Indonesian Nutrition Association 36(1):1-14

[2] Yoentafara, Alodiea dan Santi Martini. (2017). Pengaruh Pola Makan Terhadap Kadar Kolesterol Total. Surabaya : Jurnal MKMI 13(4):304-309

[3] Damanik, Siska Marina. 2013. Hubungan Pola Konsumsi Pangan Dengan Tingkat Kolesterol Darah Total Pada Pegawai Negeri Sipil Di Kanwil Direktorat Jendral Perbendaharaan Provinsi Sumatera Utara Kota Medan Tahun 2013.

[4] Nurbaiti, Mohammad Fadel Satriansyah, dan Reni Gutine. (2018). Efektivitas Ekstrak Belimbing Wuluh (Avorrhea Belimbi L.) Terhadap Kadar Kolesterol Total, High Density Lipoprotein (HDL), Dan Low Density Lipoprotein (LDL) Pada Tikus Hiperkolesterolemia. Fakultas Kedokteran Universitas Swadaya Gunung Jati

[5] Hobbs, Richard dan Bruce Arroll. 2009. Cardiovascular Risk Management. United Kingdom : Wiley-Blackwell

[6] Muhasidah, Ruslan Hasani, Indirawaty, Nur Wulan Majid. 2017. Hubungan Tingkat Pengetahuan, Sikap dan Pola Makan Dengan Kadar Gula Darah Pasien Diabetes Melitus Diwilayah Kerja Puskesmas Sudiang Kota Makassar. Jurnal Media Keperawatan 8(2):23-30

[7] Hardjojo, Basuki. 2012. Analisis Intervensi Penyuluhan Penyakit Jantung Koroner Terhadap Perubahan Tingkat Pengetahuan Dan Sikap Pegawai Universitas Terbuka Yang Berpotensi Penyakit Jantung Koroner Tahun 2011. Fakultas Kesehatan Masyarakat Universitas Indonesia. Tesis

[8] Rahman, Nurdin., Nikmah Utami Dewi, Fitra Armawaty. 2016. Faktor-faktor Yang Berpengaruh Dengan Perilaku Makan Pada Remaja SMA Negeri 1 Palu. Jurnal Preventif 7(1):43-52

[9] Kathleen MB, Weil PA, Murray RK, Graner DK, Mayes PA, Rodwell VW, Bender DA, Botham KM, editors. Biokimia Harper. Edisi 29. Jakarta; Penerbit Buku Kedokteran EGC;2012

[10] Renityas, Nevy Norma. 2020. Pendidikan Kesehatan Tentang Kolesterol Efektif Menngkatkan Pengetahuan Lansia Dalam Pencegahan Kolesterol. Program Studi D3 Kebidanan STIKES Patria Husada Blitar. Jurnal Penelitian Kesehatan 7(2):82-88

[11] Naziyah, Nuraini, dan M.Arifki Zainaro. 2018. Pengaruh Pendidikan Kesehatan Dengan Media 
Booklet Tentang Pencegaha Primer \& Sekunder Terhadap Pengetahuan Pasien Coronary Artery Disease (CAD) Di Klinik Sehat Natural Ciledug Tangerang Selatan Tahun 2016. Jurnal Kesehatan Holistik 12(1):10-20

[12] Febriyanto, Mukhammad Aminudin Bagus. 2016. Hubungan Antara Pengetahuan Dan Sikap Dengan Perilaku Konsumsi Jajanan Sehat MI Sulaimaniyah Mojoagung Jombang. Fakultas Kesehatan Masyarakat Universitas Airlangga. Skripsi

[13] Rahman, Nurdin., Nikmah Utami Dewi, Fitra Armawaty. 2016. Faktor-faktor Yang Berhubungan Dengan Perilaku Makan Pada Remaja SMA Negeri 1 Palu. Jurnal Preventif 7(1):43-52

[14] Rizqi, Alfiatur. 2018. Health Belief Model Pada Penderita Diabetes Melitus. Universitas Islam Neferi Sunan Ampel Surabaya. Skripsi

[15] Ramdhani, Neila. 2011. Penyusunan Alat Pengukur Berbasis Theory of Planned Behavior. Fakultas Psikologi Universitas Gadjah Mada. Buletin Psikologi 19 (2):55-69

[16] Kartinah, Icca Narayan P. 2009. Hubungan Tingkat Pengetahuan Dengan Sikap Keluarga Tentang Perawatan Activities Daily Living (ADL) Pada Lansia Di RUmah Di Desa Tanjungrejo Margoyoso Pati. Jurnal Berita Ilmu Keperawatan 2(2):81-86

[17] Sari, Pusvyta. 2019. Analisa Terhadap Kerucut Pengalaman Edgar Dale Dan Keragaman Gaya Belajar Untuk Memilih Media Yang Tepat Dalam Pembelajaran. Jurnal Manajemen Pendidikan 1(1):58-78

[18] Ifada, Ingga. 2010. Faktor-Faktor Yang Berhubungan Dengan Pengetahuan Masyarakat Mengenai Pelayanan Kesehatan Mata. Artikel Hasil Penelitian Karya Tulis Ilmiah. Fakultas Kedokteran Universitas Diponegoro.

[19] Herien, Puspitawati. 2008. Analisa Gender Terhadap Kebiasaan Makan Dan Faktor-Faktor Yang Mempengaruhi Perilaku Positif Pelajar Sekolah Menengah Di Kota Bogor. Media Gizi Dan Keluarga 32(1):7486

[20] Ujiani, Sri. 2015. Hubungan Antara Usia Dan Jenis Kelamin Dengan Kadar Kolesterol Penderita Obesitas RSUD Abdul Moeloek Povinsi Lampung. Jurnal Kesehatan 6(1):43-4 